\title{
Leitura, escrita, imagens e sensibilidades
}

https://doi.org/10.34112/2317-0972a2018v36n74pg-12

\section{ANDERSON Ricardo Trevisan ${ }^{1}$}

Renata Aliaga ${ }^{2}$

É COM GRANDE SATISFAÇÃo QUE APRESENTAMOS O PRESENTE NÚMERO DE Leitura: Teoria \& Prática, agora a partir de uma nova Comissão Executiva Editorial, tendo em vista a renovação da Diretoria da Associação de Leitura do Brasil para a gestão 2018-2020. Durante vários anos a revista foi muito bem conduzida por uma equipe eficiente e empenhada em levar adiante o desafio de publicar quadrimestralmente uma revista dedicada à leitura no seu sentido mais amplo. A nova Comissão agradece imensamente o trabalho realizado por Davina Marques e demais colegas e esperamos fazer jus a essa bela e desafiadora missão.

A revista Leitura: Teoria \& Prática $\mathrm{n}^{\circ} 74$ traz artigos que tratam da questão da leitura e do letramento em suas mais variadas formas e possibilidades, da poesia ao conto infantil, da linguagem escrita ao universo da LIBRAS. Nesse meio campo, houve espaço para se falar de imagens e memórias, de subjetividade e de letramento como instrumento de transformação de realidades.

O artigo de abertura, de Jilvania Lima dos Santos Bazzo, Lilane Maria de Moura Chagas e Fernando José Fraga de Azevedo, fala sobre a importância da presença da poesia no universo escolar. A poesia, ao ser levada para sala de aula,

1. Universidade Estadual de Campinas, Campinas, SP, Brasil.

2. Instituto Federal de São Paulo, Campinas, SP, Brasil. 
contribui para o desenvolvimento de competências linguísticas e literárias, amplia conhecimentos culturais e históricos, e ainda permite um mergulho no universo dos afetos e sensibilidades. Trata-se, portanto, de um instrumento de conhecimento e humanização, o que justifica sua presença na vida dos estudantes desde a mais tenra idade.

Em "Práticas de leitura e escrita na educação infantil: o texto como unidade de sentido", Keylla Rejane Almeida Melo e Antonia Edna Brito apresentam o resultado de uma pesquisa realizada em dois Centros Municipais de Educação Infantil de Teresina-PI, sobre suas práticas de leitura e de escrita com crianças, na faixa etária de 03 a 06 anos de idade. $\mathrm{O}$ artigo aponta que, embora haja a mobilização de textos literários pelas professoras responsáveis, o interesse não é a interpretação do texto em si ou a formação de leitores, mas sim um uso mecânico da literatura para fins de desenvolvimento das habilidades linguísticas.

Caminhando ao lado de Vigotski e Paulo Freire, Solange da Silva Souza e Paulo Demetrio Pomares da Silva discutem o tema da afetividade, considerada elemento fundamental na formação do leitor literário. Os mediadores responsáveis por esse processo de desenvolvimento da afetividade entre alunos e textos literários são apresentados a partir da imagem de Cupido, figura mitológica "que desperta o amor entre aqueles que por ela são flechados". Nesse cenário, torna-se fundamental o estabelecimento de um elo de afetividade entre o professor, ou leitor experiente, com os leitores em formação, promovendo assim uma compreensão real do uso da linguagem escrita em situações significativas de aprendizagem.

O universo da literatura infantil reaparece no artigo "Leitura e interlocução na sala de aula: um olhar para a produção e circulação de sentidos". A partir da leitura oral do conto A pequena vendedora de fósforos, do autor dinamarquês Hans Christian Andersen (1805 - 1875), Giovana Tolesani Camargo Barbosa e Ana Lúcia Guedes-Pinto buscam analisar as interlocuções entre os sujeitos (professora e alunos) no cotidiano de uma sala de aula, e com isso encontrar indícios dos sentidos elaborados pelas crianças em meio às atividades escolares. Os sentidos atribuídos ao conto pelos alunos puderam ser percebidos, por exemplo, durante sua leitura em voz alta, a partir das reações das crianças, mas também pela atividade de reescrita do conto realizada por eles posteriormente. "Nesse processo, destaca-se o papel da prática de leitura [...], pois ela pôde fomentar a interlocução entre os sujeitos e deles com o material lido, permitindo que os sentidos circulassem mais livremente", concluem as autoras. 
O artigo " $(\mathrm{Re})$ construindo aulas de Língua Portuguesa no diálogo entre universidade e escola" traz os resultados de um projeto de extensão realizado na Faculdade de Artes, Comunicação e Letras (FACALE) da Universidade Federal da Grande Dourados (UFGD) sobre a leitura e a escrita de gêneros que fazem parte do cotidiano de ensino das escolas, envolvendo docentes da educação básica, professores universitários e alunos do curso de Letras. O artigo de Lúcia Cherem e Suellym Opols também traz o resultado de um projeto, desta vez sobre o letramento de crianças surdas, realizado a partir de vários trabalhos realizados com o livro Alice no País das Maravilhas, de Lewis Caroll.

A sessão ensaios traz dois textos. $\mathrm{O}$ primeiro, "O desafio da interculturalidade frente ao letramento literário", de Diego Pereira, discute a relação entre literatura, letramento e sociedade, defendendo o cultivo de uma experiência estética liberadora e progressista, na qual o letramento literário seja um instrumento de transformação da realidade social. $\mathrm{O}$ segundo texto fala sobre imagens, memória e subjetividade. Margareth Correia Fagundes Costa, partindo teoricamente de Bergson e empiricamente de fotografias de seu acervo pessoal, mobiliza o conceito de memória-lembrança para destacar que as temporalidades nunca são lineares, e que "passado é contemporâneo ao presente que está passando". As imagens, nesse sentido, podem ser pensadas como gatilhos para o passado, numa imersão que nos convida a pensar a própria história, que é sempre movimento. Afinal, como diz Walter Benjamin, a verdadeira imagem do passado perpassa velozmente, mas esse passado se deixa fixar, como imagem que relampeja, quando ele é reconhecido. ${ }^{3}$ Benjamin fala sobre a urgência em se reconhecer o passado e com ele aprender. No mesmo texto, cita uma imagem de Paul Klee, o Angelus Novus, figura de "um anjo que parece querer afastar-se de algo que ele encara fixamente. Seus olhos estão escancarados, sua boca dilatada, suas asas abertas. O anjo da história deve ter esse aspecto. Seu rosto está dirigido para o passado. Onde nós vemos uma cadeia de acontecimentos, ele vê uma catástrofe única, que acumula incansavelmente ruína sobre ruína a asa dispersa a nossos pés". ${ }^{4}$ Benjamin parte de uma obra de arte para nos alertar sobre a importância de se conhecer o passado, a história, de uma forma questionadora e não linear.

3. Walter BENJAMIN, "Sobre o conceito de história", In: Obras escolhidas I: Magia e técnica, arte e política. Ensaios sobre literatura e história da cultura, Brasiliense, 1995, p. 224.

4. Walter BENJAMIN, “Sobre o conceito de história”, op. cit., 1995, p. 226. 
Os artigos reunidos nesta edição, de algum modo, nos conduzem a uma discussão semelhante: sobre a importância da mobilização da literatura nas escolas, não apenas por conta de seu reconhecido papel no letramento das crianças, mas também pela possibilidade de construir sensibilidades e mentes críticas que valorizem a pluralidade de ideias e opiniões, o diálogo e o espírito democrático. 